Physical Therapy Journal of Indonesia (PTJI) 2020, Volume 1, Number 2: 38-40

E-ISSN : 2722-6034; P-ISSN : 2722-0125

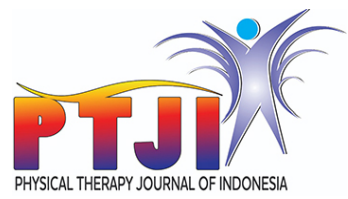

\title{
Explosive Power of Front Kick in The Perform of Martial Art Athletes
}

\author{
Bayu Prastowo ${ }^{1 *}$, Safun Rahmanto ${ }^{1}$
}

'Physiotherapy Department, Universitas Muhammadiyah Malang, Indonesia
*Corresponding author: Bayu Prastowo; Physiotherapy Department, Universitas Muhammadiyah Malang, Indonesia; bprastow024@gmail.com
Received : 2020-06-29 Accepted : 2020-11-26 Published : 2020-12-01

\section{ABSTRACT}

Introduction: Martial art is a new sport that first competed in the 18th Asian Games. The front kick techniques in matches are more often used than other techniques. This study aims to identify whether Contract-Relax Stretching (CRS) affects the athlete's front kick explosive power performance.

Methods: This study uses one group pre-test post-test design approach. The sample population was 30 respondents. Martial art athletes are given CRS.

Results: Analysis probability value shows significant $p<0.001$, whereas vertical jump test increased the explosive power performance from poor to average and average to good.

Conclusion: Performance of explosive power in the front kick of martial arts athletes increases after being given a CRS.

Keywords: contract-relax stretching, explosive power, front kick, martial art athlete, vertical jump test

Cite this Article: Prastowo, B., Rahmanto, S. 2020. Explosive Power of Front Kick in The Perform of Martial Art Athletes. Physical Therapy Journal of Indonesia 1(2): 38-40.

\section{INTRODUCTION}

Indonesian government included martial art in the 18th Asian Games sports to preserve this sport's preservation, wisdom, and development. Martial art kick techniques in the competition are the front-kick, back-kick, and side-kick. ${ }^{1}$ The kicking technique in the match is more dominant than the other techniques. Percentage of front-kick 44\%, $33 \%$ punch, $19 \%$ catch and fall, $4 \%$ defense. That is because the kicking technique has a higher point compared to the hand attack technique.

The front-kick function is an attack and opening defense. The front kick mechanism involves the joints (hip joints, knee joints, ankle joints) and soft tissues (hamstring, quadriceps). Flexi $90^{\circ}$ was on the knee joint as a prefix is followed by kicking (knee joint extension), lower leg followed by phalanx joint extension as a form of a kick. Front-kick has the advantage of being very useful for fights with longrange or for the fighter who has right leg length and kick strength. ${ }^{2}$

Front-kick requires explosive power as a supporting ability to improve reliable and fast physical characteristics in carrying out attacks and opening defenses. Explosive power is part of the maximum power and maximum speed. Stretching is the protocol for improving an athlete's overall function, flexibility, and injury prevention. ${ }^{3}$

Contract-Relax Stretching (CRS) is part of Proprioceptive Neuromuscular Facilitation (PNF) stretching. ${ }^{4}$ CRS mechanism utilizes the body's anatomical and physiological reflexes to respond progressively to stretching. CRS technique provides effectiveness in the elongation process of soft tissue structures such as fascia, muscle, ligament and tendon. That it can increase the range of movement (ROM) and decrease pain due to shortening of soft tissue. While the main components of explosive power performance are flexibility, strength and time. ${ }^{5}$

This study aimed to evaluate whether the CRS on front-kick muscles (including quadriceps and hamstring) would improve martial art athletes' vertical jump.

\section{METHODS}

\section{Participants}

The study participants were 30 male martial art athletes of Persaudaraan Setia Hati Terate, Universitas Muhammadiyah Malang, Indonesia. They were recruited by using purposive sampling. The study participants' inclusion criteria were those athletes who were restricted on the knee ROMs and hip ROMs. Participants who had joint hypermobility, neuromuscular disease, unhealed lower limb injury, or could not understand instructions because of any disability were excluded from this study. All participants agreed to participate in this study and written informed consent was obtained from each participant.

\section{Data collection and intervention}

Muscles' explosive power was measured through the vertical jump test (VJT) before- and after the 
intervention. VJT was measured by measuring tape with $1 \mathrm{~cm}$ incremental. Participant stood beside the wall marked with measuring tape, and one hand reached up closest to the wall. With the feet flat on the ground, the point of fingertip was marked. Participants put chalk on their fingertips to mark the wall at the height of his/her jump. Participants then stood away from the wall and jumped vertically as high as possible, using both legs and arms to assist the body projected upward to touch the wall at the highest point of the jump. As an independent data collector, a PT calculated the distance between the standing reach height and the jump height. All participants performed three times VJT, and the average score was used in this study outcome. ${ }^{6}$

CRS was given three times per week for two weeks. All participants performed a short warmup, i.e., jogging for 2 mins before the CRS. Within the CRS, each muscle group was subjected to 4 CRS cycles, including a $10 \mathrm{~s}$ of strong contraction (participants were told to contract their muscles by $70 \%$ of their maximum force) and $2-5 \mathrm{~s}$ of relaxation, and 10-15 s of passive stretching by a PT.

Table 1. Comparisons of the vertical jump test at the baseline and their changes over the 2-week intervention period of contract-relax stretching (CRS).

\begin{tabular}{ccccc}
\hline Category & Value Range & $\begin{array}{c}\text { Pre-CRS } \\
\boldsymbol{n}(\%)\end{array}$ & $\begin{array}{c}\text { Post-CRS } \\
\boldsymbol{n}(\%)\end{array}$ & $\boldsymbol{p}$-value \\
\hline Exellent & $>81 \mathrm{~cm}$ & $0(0.0)$ & $0(0.0)$ & \\
Very Good & $66-80 \mathrm{~cm}$ & $0(0.0)$ & $0(0.0)$ & \\
Good & $56-65 \mathrm{~cm}$ & $0(0.0)$ & $1(3.3)$ & $<0.0001$ \\
Average & $46-55 \mathrm{~cm}$ & $13(43.3)$ & $16(53.3)$ & \\
Poor & $>45 \mathrm{~cm}$ & $17(56.7)$ & $13(43.3)$ & \\
\hline
\end{tabular}

$n$, number of participants

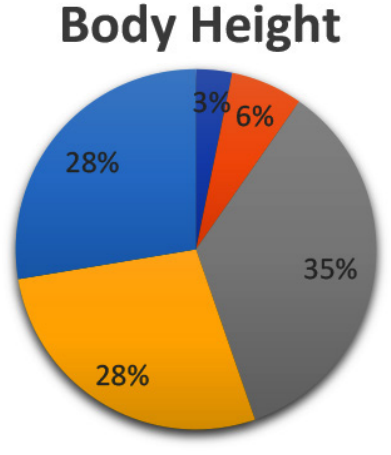

— 150-155 — 156-150 = 161-165

다-166-170 $171-175$

Figure 1. Characteristics of respondents by body height

\section{Body Weight}

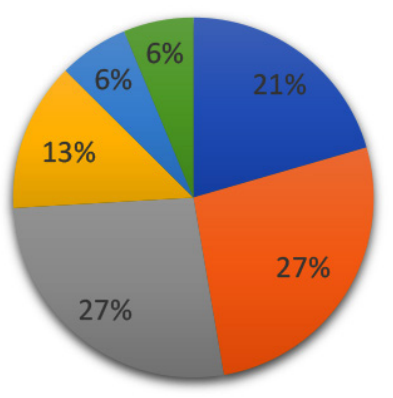

घ45-50 = 51-55 $=56-60$

घ61-65 घ 66-70 च 70-75

Figure 2. Characteristics of respondents by body weight
The CRS sequence was the left leg's hamstrings first, followed by the left leg's quadriceps, then followed on the right leg with the same sequence.

During the study period, respondents were not allowed to do other stretching activities and suggested avoiding activities that would irritate the muscles (fighting, jumping, running) to minimizes errors in the accuracy of research data.

\section{Statistical analysis}

We used descriptive analysis to calculate the demographic data. The Shapiro-Wilk was used to evaluate the normality distribution of pre-CRS' VJT and post-CRS' VJT. To evaluate CRS effectiveness, we used Paired T-Test between the pre-CRS' VJT and post-CRS' VJT.

\section{RESULTS}

In Figure 1 showed patient body height characteristic, of thirty athletes, ten (35\%) athletes who had $161-165 \mathrm{~cm}$ and eight (28\%) athletes had $171-175 \mathrm{~cm}$. In The body weight showed in figure 2, there were eight (27\%) athletes who had the 51-55 $\mathrm{kg}$ and $56-60 \mathrm{~kg}$, and only two (6\%) athletes who had $66-70 \mathrm{~kg}$ and $70-75 \mathrm{~kg}$.

Normality analysis of data pre- and post-CRS interventions using Shapiro-Wilk obtained the normally distributed data ( $p$-value: pre-CRS = 0.970 , post-CRS $=0.502)$. All respondents gave an increase in VJT after CRS in the range of $2-7 \mathrm{~cm}(p$ $=<0.0001)$.

\section{DISCUSSION}

CRS and explosive power relationship might be explained by the theory of autogenic inhibition, reciprocal inhibition, stress relaxation, and gate control. CRS passively stretched the muscle to the point of maximum flexibility (second pain), it possibly carried out with isotonic contractions. ${ }^{7}$ The force was progressive, while resistance by increasing their isotonic strength. Increased isotonic strength will cause the addition of strain to the tendon. Therefore the Golgi Tendon Organs (GTOs) got harder stimulation. ${ }^{8}$ The stimulation caused the GTOs to reach the threshold of the stimulation. The stronger the muscle was stretch and contraction. ${ }^{9}$ If the muscle contracted for more than $6 \mathrm{~s}$, then the contraction suddenly stoped, that would make the muscles relax. Potential strain during relaxation gave an inhibitory effect, namely autogenic inhibition reflex. ${ }^{10}$ As a result of this relaxation, a sudden force to lose resistance caused a muscle lengthen after isotonic contraction that associated with increased of muscles endurance and power. ${ }^{11}$ 
CRS technique stretched the muscles through eccentric muscle movements, which has an elastic component, consisting of connective tissue surrounding each muscle tissue layer. This stretching influenced the stretch-shortening cycle, which explained the mechanoreceptor was stimulated inside the muscle, called the muscle spindle fiber, and sent receptor signals to the spinal cord. ${ }^{12}$ The stimulation continued to the effector's nerves in the form of muscle contraction orders, then produced movements controlled by the motor cortex in the frontal lobe. Thus, CRS increased muscle lengthening, muscle strength, and muscular endurance through contractions, accompanied by isotonic movements. ${ }^{13}$

This study had several limitations. Firstly, this study did not have a control group of placebo intervention or another type of stretching. Thereby, this study's results did not discriminate whether CRS or natural changes caused the changes in VJT. Secondly, this study results might not be generalized to all male martial art athletes in Indonesia. Our study participants were relatively small in this sport area. In Indonesia, many martial art athletes spread outside of our study setting that we could not recruit because of a limited source.

\section{CONCLUSION}

This study concluded that the CRS improved the explosive power of front-kick muscles in perform martial art athletes. However, the improvement could not be ascertained from the intervention or natural changes. The addition of participants and a control group were suggested to achieve a better generability and accuracy of the results, respectively.

\section{CONFLICT OF INTEREST}

The authors declare no competing interest in this research study.

\section{FUNDING}

N/A

\section{ACKNOWLEDGEMENT}

The authors were grateful to the Physiotherapy Department, University of Muhammadiyah Malang and Persaudaraan Setia Hati Terate (PSHT) Organization of Indonesian martial art.

\section{AUTHOR CONTRIBUTIONS}

BP conceived the research study design, data collections, data analysis, drafted the paper, and SR conducted the study design, data collections, data analysis data, and drafted the paper,

\section{REFERENCES}

1. Anam AK, Hidayah T. Analisis gerak tendangan depan pada ekstrakurikuler pencak silat. Journal of Sport Science and Fitness. 2014;3(3).

2. Frederick A, Frederick C, Myers TW. Fascial stretch therapy: Handspring Publishing; 2014.

3. Malliaropoulos N, Papalexandris S, Papalada A, Papacostas E. The role of stretching in rehabilitation of hamstring injuries: 80 athletes follow-up. Med Sci Sports Exerc. 2004;36(5):756-9.

4. Morcelli MH, Oliveira JMCA, Navega MT. Comparison of static, ballistic and contract-relax stretching in hamstring muscle. Age (years). 2013;20(1.57):21.31-1.5 .

5. Tsolakis C, Bogdanis GC. Acute effects of two different warm-up protocols on flexibility and lower limb explosive performance in male and female high level athletes. J Sports Sci Med. 2012;11(4):669.

6. Petschnig $\mathrm{R}$, Baron $\mathrm{R}$, Albrecht $\mathrm{M}$. The relationship between isokinetic quadriceps strength test and hop tests for distance and one-legged vertical jump test following anterior cruciate ligament reconstruction. J Orthop Sports Phys Ther. 1998;28(1):23-31.

7. Cayco CS, Labro AV, Gorgon EJR. Hold-relax and contractrelax stretching for hamstrings flexibility: A systematic review with meta-analysis. Phys Ther Sport. 2019;35:42-55.

8. Magnusson SP, Simonsen EB, Aagaard P, Dyhre-Poulsen P, McHugh MP, Kjaer M. Mechanical and physiological responses to stretching with and without preisometric contraction in human skeletal muscle. Arch Phys Med Rehabil. 1996;77(4):373-8.

9. Hindle K, Whitcomb T, Briggs W, Hong J. Proprioceptive neuromuscular facilitation (PNF): Its mechanisms and effects on range of motion and muscular function. Journal of human kinetics. 2012;31(2012):105-13.

10. van Ingen Schenau GJ, Bobbert MF, de Haan A. Mechanics and energetics of the stretch-shortening cycle: a stimulating discussion. J Appl Biomech. 1997;13(4):484-96.

11. Feland J, Marin H. Effect of submaximal contraction intensity in contract-relax proprioceptive neuromuscular facilitation stretching. Br J Sports Med. 2004;38(4):e18-e.

12. Ishikawa M, Komi PV. Effects of different dropping intensities on fascicle and tendinous tissue behavior during stretch-shortening cycle exercise. J Appl Physiol. 2004;96(3):848-52.

13. Handel M, Horstmann T, Dickhuth H-H, Gülch R. Effects of contract-relax stretching training on muscle performance in athletes. Eur J Appl Physiol Occup Physiol. 1997;76(5):400-8.

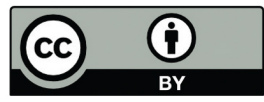

This work is licensed under a Creative Commons Attribution 